\title{
The spatiotemporal changes of marshland and the driving forces in the Sanjiang Plain, Northeast China from 1980 to 2016
}

\author{
Zhen $\mathrm{Li}^{1,2}$, Miao Liu' ${ }^{*}$, Yuanman $\mathrm{Hu}^{1}$, Zhenshan $\mathrm{Xue}^{3}$ and Jinling Sui ${ }^{2,4}$
}

\begin{abstract}
Background: Wetland loss is a global concern due to its enormous ecosystem services. Marshland, a typical natural wetland, which is concentrated in the Sanjiang Plain, has undergone dramatic loss in the last several decades. The spatiotemporal changes in marshland were studied based on Landsat images of the Sanjiang Plain from 1980 to 2016 with the land use maps in 1980, 1995, 2000, 2005, 2010, and 2016 using land use dynamic degree and landscape indices. The driving forces of marshland loss, including biophysical factors, socio-economic factors, and land management, were analyzed with boosted regression trees (BRTs) methods.

Results: The area of marshland loss was $7372 \mathrm{~km}^{2}$, which accounted for $65.7 \%$ of the area of marshland in 1980; however, the paddy field area was expanded by $22,313 \mathrm{~km}^{2}$. The lost marshland was mainly converted to dry farmland (47.5\%) and paddy field (47.2\%) during 1980-2016. Both the landscape pattern of the study area and marshland became increasingly fragmented. The relatively important factors responsible for marshland loss were biophysical factors, socio-economic factors, and land management, which accounted for $65.2 \%, 25.5 \%$, and 8.4\%, respectively. The most important driving forces with high "relative influence" were "distance to river," which accounted for $20.6 \%$ of the total variance explained. The "relative influence" of potential crop yield and ditch density reached $20.2 \%$ and $8.4 \%$, respectively.

Conclusion: Significant land use changes have occurred in the Sanjiang Plain over the past 37 years, with characteristics of rapid paddy field expansion and drastic marshland loss. Meanwhile, marshland fragmentation continued to increase. Reclamation was the main reason for the large-scale marshland loss. Biophysical factors influenced the decisions regarding the locations of marshland loss. Moreover, climate factors (i.e., average annual precipitation and average annual temperature) also played an important role in marshland loss. These results can provide helpful knowledge for understanding the patterns and reasons for marshland loss and protecting and managing strategies for wetlands restoration.
\end{abstract}

Keywords: Land use change, Marshland loss, Driving forces, The Sanjiang Plain

\footnotetext{
* Correspondence: lium@iae.ac.cn

${ }^{1}$ CAS Key Laboratory of Forest Ecology and Management, Institute of Applied

Ecology, Chinese Academy of Sciences, Shenyang 110016, China

Full list of author information is available at the end of the article
}

\section{Springer Open}

(c) The Author(s). 2020 Open Access This article is licensed under a Creative Commons Attribution 4.0 International License, which permits use, sharing, adaptation, distribution and reproduction in any medium or format, as long as you give appropriate credit to the original author(s) and the source, provide a link to the Creative Commons licence, and indicate if changes were made. The images or other third party material in this article are included in the article's Creative Commons licence, unless indicated otherwise in a credit line to the material. If material is not included in the article's Creative Commons licence and your intended use is not permitted by statutory regulation or exceeds the permitted use, you will need to obtain permission directly from the copyright holder. To view a copy of this licence, visit http://creativecommons.org/licenses/by/4.0/. 


\section{Introduction}

Wetlands play an irreplaceable role in hydrologic regulation, carbon storage, water purification, and biodiversity conservation (Bullock and Acreman 2003; Costanza et al. 2014). However, wetland loss has occurred worldwide due to increasing human activity and global climate change (Junk et al. 2013; Gardner et al. 2015). It has been reported that more than half of the natural wetlands have been lost (Gardner et al. 2015; Davidson et al. 2018). Furthermore, wetlands continue to shrink as the increasing demands for land and climate change, particularly in Asia and at mid-high latitudes zone (Davidson 2014; Dixon et al. 2016). Due to agricultural reclamation and urbanization, $60 \%$ and $6 \%$ of the wetlands in China were lost from 1990 to 2010, respectively (Mao et al. 2018a, 2018b). Wetland loss can result in the decline in ecosystem services, such as an increase in greenhouse gas emissions, and a reduction in the water supply (Finlayson et al. 1999). Wetland restoration is necessary in places where wetlands have been lost to enhance ecosystem services (Liu et al. 2013). Clarifying the patterns and dynamics of wetland changes is a fundamental issue in wetland restoration. Furthermore, the underlying forces of wetland loss must be identified to implement sustainable management strategies for wetlands.

The reasons for wetland loss are complex and diverse. Commonly, wetland loss can ascribed to human activity, natural disturbances, or interaction effects (van Asselen et al. 2013; Pekel et al. 2016; Thomas et al. 2017). Drainage to gain arable or built-up land, exhaustion for wetland sources, aquaculture, and water conservancy projects (e.g., ditch regimes, reservoirs, polders), infrastructure construction (e.g., roads), and biological invasions are the most common human activities (Deegan et al. 2012; van Asselen et al. 2013). Sea-level rise, droughts, storms, burning, and subsidence are common natural factors in ecologically fragile areas that cause wetland changes (Turetsky et al. 2015; Feller et al. 2017; Morris et al. 2018).

Analysis of the driving forces of land use and land cover changes is one of the vital parts of land use change and land cover research. A common method that used to explain the relationship between land use change and driving forces of land use change is the combination of a conceptual model with a mathematical model (Zhang et al. 2017). Geist and Lambin's theoretical framework successfully identified the underlying and proximate driving forces of tropical deforestation (Geist and Lambin 2002). Statistical methods are commonly used to analyze the relationship between wetland loss and explanatory variables, such as partial least squares regression, partial correlation analysis, linear correlation, logistic regression, gray correlation, and multiple stepwise regression (van Asselen et al. 2013; Meng et al. 2017). Meanwhile, machine learning (e.g., random forest method) methods have gradually been applied in land use change studies (Zanella et al. 2017).
The Sanjiang Plain has undergone significant changes in land use, especially large-scale marshland loss, since the 1950s. Many studies have evaluated the land use and landscape pattern changes throughout the region or in part of the region at different time scales (Li et al. 2002; Liu et al. 2013; Yan et al. 2017; Liu et al. 2018). However, their land use classification systems were relatively coarse (e.g., they did not separate marshland from wetland or the paddy field from farmland), and few studies paid attention to combine the change of regional landscape pattern with marshland landscape pattern. Considering the Chinese government policy (e.g., the Household Production Responsibility System) conducted in 1978, it is necessary to assess the landscape pattern change since 1980. Additionally, few studies have quantitatively the driving forces of marshland loss by combining natural and socio-economic data, especially land management. The marshland and paddy field were separated to analyze the regional landscape pattern change from 1980 to 2016. Additionally, the ditch regime was regarded as one driving force to explain marshland loss.

The objectives of this study are as follows: (1) renew the land use map of the study area to 2016 of the study area and evaluate the land use and landscape changes with the land use map since 1980 and (2) quantitatively analyze the driving forces of marshland loss with natural and socio-economic factors during 1980-2016, especially regarded ditch density as one driving forces of marshland loss.

\section{Materials and methods \\ Study site}

The Sanjiang Plain $\left(130^{\circ} 13^{\prime}-135^{\circ} 05^{\prime} \mathrm{E}, 45^{\circ} 01^{\prime}-48^{\circ} 27^{\prime}\right.$ N) has an area of $10.8 \times 10^{4} \mathrm{~km}^{2}$ and is located in Northeast China. The climate is a temperate continental monsoon climate, with an average annual precipitation of 500-650 mm and an average annual temperature of $1.4-4.3{ }^{\circ} \mathrm{C}$. As the core of the wetlands in the area, the marshland in the Sanjiang Plain has undergone significant shrinkage and fragmentation due to the high-intensity reclamation since the 1950s. Since the 1990s, a series of wetland restoration programs have been conducted by the government to conserve and restore the natural wetlands. To date, five natural reserves have been listed as Ramsar wetlands (Fig. 1).

\section{Data acquisition and collection}

Landsat TM (Thematic Mapper) and OLI (Operational Land Imager) cloudless images were obtained from the United States Geological Survey Earth Resources Observation and Science Center (USGS, 2016) between April and October in 1980, 1995, 2000, 2005, 2010, and 2016. After radiation calibration and image enhancement, the images were geometrically corrected with 1:100,000 topographic map in 1982. Uniform coordinates and projection, 


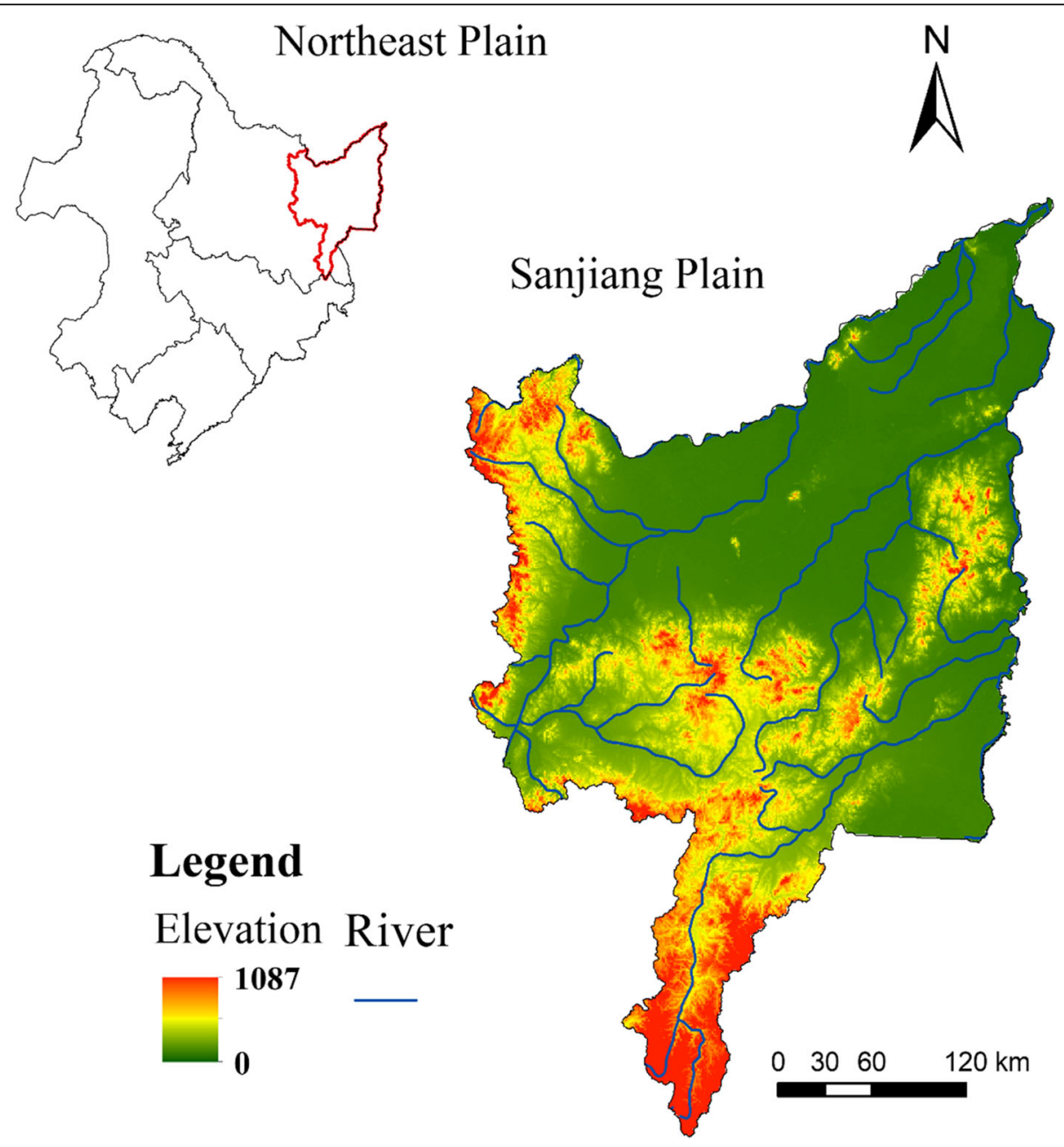

Fig. 1 Location map of the study area

the images in different periods were rectified to the Beijing 1954 Krasovsky Albers project. After image mosaicking, a supervised classification and visual interpretation approach was applied to interpret the land use map. Land use types include paddy field, dry farmland, grassland, forestland, water area, built-up land, and marshland.

The driving forces, including the gross domestic product (GDP), population density, elevation, slope, potential crop yield, annual average precipitation, and annual average temperature, were downloaded from the Data Center for Resources and Environmental Sciences, Chinese Academy of Sciences (RESDC) (http://www.resdc.cn). All driving forces and map of marshland loss were resampled to $1 \mathrm{~km} \times 1 \mathrm{~km}$ in ARCGIS 10.3.

\section{Methods}

\section{Single land use dynamic degree}

This metric was used to quantify the land use changes. The expression is as follows:

$$
K=\frac{U_{b}-U_{a}}{U_{a}} \times \frac{1}{T} \times 100 \%
$$

Notes: $\mathrm{K}$ is the single land use dynamic degree, $U_{a}$ is the initial area, $U_{b}$ is the terminal area, and $T$ is the duration.

\section{Landscape pattern analysis}

Landscape indices are powerful methods for landscape pattern change analysis. Based on previous studies (Xiao et al. 1990; Li et al. 2005), six class-level metrics and landscape-level metrics were applied to assess the landscape pattern changes considering their ecological meaning (Table 1). The indices used to characterize the landscape patterns from 1980 to 2016 are as follows: landscape-level metrics, including number of patches (NP), landscape shape index (LSI), contagion (CONTAG), patch cohesion index (COHESION), Shannon's diversity index (SHDI), and Shannon's evenness index (SHEI), and class-level metrics, besides NP, LSI, and 
Table 1 Landscape metrics

\begin{tabular}{|c|c|c|}
\hline $\begin{array}{l}\text { Indices/ } \\
\text { units }\end{array}$ & Metrics & Description \\
\hline NP (none) & $\begin{array}{l}\text { Class/ } \\
\text { landscape }\end{array}$ & Number of patches \\
\hline LPI (\%) & Class & $\begin{array}{l}\text { Percentage of the total area comprised by } \\
\text { area of the largest patch }\end{array}$ \\
\hline $\begin{array}{l}\text { SPLIT } \\
\text { (none) }\end{array}$ & Class & $\begin{array}{l}\text { Square of the total area divided by the sum } \\
\text { of square of each patch area }\end{array}$ \\
\hline $\mathrm{ED}\left(\mathrm{m} / \mathrm{km}^{2}\right)$ & $\begin{array}{l}\text { Class/ } \\
\text { landscape }\end{array}$ & $\begin{array}{l}\text { Sum of length of all edge segments divided } \\
\text { by the total area }\end{array}$ \\
\hline LSI (none) & $\begin{array}{l}\text { Class/ } \\
\text { landscape }\end{array}$ & $\begin{array}{l}\text { The deviation between the patch and same } \\
\text { area of the circle }\end{array}$ \\
\hline $\begin{array}{l}\text { COHESION } \\
\text { (none) }\end{array}$ & $\begin{array}{l}\text { Class/ } \\
\text { landscape }\end{array}$ & $\begin{array}{l}\text { The physical connectedness of the } \\
\text { corresponding patch type }\end{array}$ \\
\hline $\begin{array}{l}\text { CONTAG } \\
(\%)\end{array}$ & Landscape & It considers all types present on an image \\
\hline SHDI (none) & Landscape & $\begin{array}{l}\text { It is used to compare landscape diversification } \\
\text { and landscape heterogeneity of different } \\
\text { landscapes or same landscape at different } \\
\text { times }\end{array}$ \\
\hline SHEl (none) & Landscape & $\begin{array}{l}\text { It is used to expressed the maximum } \\
\text { evenness when an even distribution of area } \\
\text { among patch type }\end{array}$ \\
\hline
\end{tabular}

Table 2 Driving forces and possible effects

\begin{tabular}{|c|c|c|}
\hline Driving forces & Possible effects & Sources and types \\
\hline \multicolumn{3}{|l|}{ Biophysical factors } \\
\hline Distance to river $(\mathrm{m})$ & Marshland near river exhibited fewer loss & River was from land use map in 2016 and then GIS analysis: Vector data \\
\hline Elevation (m) & Marshland in lower areas more prone to loss & GIS analysis of data from RESDC: Raster, $30 \mathrm{~m}$ \\
\hline Slope $\left(^{\circ}\right)$ & $\begin{array}{l}\text { Marshland loss is more likely to occur in flat } \\
\text { areas }\end{array}$ & GIS analysis based on the elevation: Raster \\
\hline $\begin{array}{l}\text { Average annual } \\
\text { precipitation (mm) }\end{array}$ & $\begin{array}{l}\text { The marshland loss rate increase with } \\
\text { decrease precipitation }\end{array}$ & GIS analysis of data from RESDC: Raster \\
\hline $\begin{array}{l}\text { Average annual } \\
\text { temperature }\left({ }^{\circ} \mathrm{C}\right)\end{array}$ & $\begin{array}{l}\text { Marshland are more likely to be converted at } \\
\text { warmer temperatures }\end{array}$ & GIS analysis of data from RESDC: Raster \\
\hline $\begin{array}{l}\text { Potential crop yield } \\
\left(\mathrm{kg} / \mathrm{km}^{2}\right)\end{array}$ & $\begin{array}{l}\text { Marshland are more likely to be converted } \\
\text { when potential crop yields are high }\end{array}$ & GIS analysis of data from RESDC: Raster \\
\hline \multicolumn{3}{|l|}{ Socio-economic factors } \\
\hline $\begin{array}{l}\text { Distance to settlement } \\
(\mathrm{m})\end{array}$ & $\begin{array}{l}\text { Marshland tend to be vulnerable to losses } \\
\text { when adjacent to residents }\end{array}$ & Settlements was from land use map in 2016: Vector data \\
\hline Distance to road (m) & Marshland near roads tend to be prone to loss & GIS analysis of data from RESDC: Vector data \\
\hline $\begin{array}{l}\text { Gross domestic product } \\
\text { (yuan } / \mathrm{km}^{2} \text { ) }\end{array}$ & $\begin{array}{l}\text { Marshland distributed in the poor areas are } \\
\text { more likely to be lost }\end{array}$ & GIS analysis of data from RESDC: Raster \\
\hline $\begin{array}{l}\text { Population density } \\
\text { (persons } / \mathrm{km}^{2} \text { ) }\end{array}$ & $\begin{array}{l}\text { Marshland loss is more likely to occur in high- } \\
\text { density population areas }\end{array}$ & GIS analysis of data from RESDC: Raster \\
\hline \multicolumn{3}{|l|}{ Land management factors } \\
\hline $\begin{array}{l}\text { Ditch density } \\
\text { (length/km²) }\end{array}$ & $\begin{array}{l}\text { Marshland in the region with high ditch } \\
\text { density are more likely to be prone to loss }\end{array}$ & $\begin{array}{l}\text { Ditch regime was digitized from the Atlas of Water Conservancy Projects } \\
\text { Present Situations in Heilongjiang Reclamation Area 2010: Vector data }\end{array}$ \\
\hline
\end{tabular}

COHESION, as well as largest patch index (LPI), edge density (ED), and splitting index (SPLIT).

\section{Driving forces analysis}

Based on land use maps of 1980 and 2016, marshland loss map was extracted. A systematic grid method was imposed to generate points, and each point spaced $1 \mathrm{~km}$ apart to avoid potential spatial autocorrelation. The points were intersected with marshland loss and all the explanatory variables for BRTs analysis. analyze the driving forces, which is a machine learning method, that is useful for identifying the driving forces in land use conversion (Wendland et al. 2011; Müller et al. 2013). Compared to the traditional statistical approach, BRTs do not make any assumptions on the distribution of land use changes and driving forces, do not overfit, and have high predictive accuracy (Elith et al. 2006; Dormann et al. 2013). Meanwhile, BRTs are robust against collinearity of the driving forces. Nevertheless, Pearson's correlation coefficient matrix was calculated to assess the collinearity of the driving forces. When the correlation between two driving forces was $\geq$ 0.7 , the driving forces that had less clear relationship with the marshland loss would be removed. BRTs have gradually received increasing attention in land use science (Lara et al. 2016; Sica et al. 2016). The BRTs have been used to adequately explain the drivers of
Boosted regression trees (BRTs) were selected to 
intensification in thermokarst rates intensify due to climate change and forest fragmentation in an Alaskan boreal forest lowland (Lara et al. 2016), patterns of intensified forest harvesting (Levers et al. 2014), agricultural intensification (Levers et al. 2016), and wetland loss (Sica et al. 2016).

The dismo package (Elith et al. 2008) in R3.4.1 was used to perform all analyses. A systematic sensitivity analysis was conducted to calibrate the model, and a detailed description was available in Lara's reference (Lara et al. 2016). A total of 11 driving forces were selected (Table 2), including biophysical factors, socio-economic factors, and land management factors.

The first group of explanatory variables captured biophysical factors. As a majority of marshland was distributed near the river, we included (1) distance to river. Marshland loss was related to topography because it determines the water flow, so we included (2) elevation and (3) slope. The precipitation and temperature can cause fluctuations in the marshland area, so we included (4) the average annual precipitation and (5) the average annual temperature. Soil quality was another possible variable that could explain marshland loss, so we included (6) potential crop yield.

The second group of explanatory variables involved socio-economic factors. Marshland located near roads or settlements is easily accessible and more vulnerable to loss (van Asselen et al. 2013), so we included (1) distance to settlement and (2) distance to road. The causes of marshland loss were mainly associated with population growth and increasing income levels, so we included (3) GDP and (4) population density.

The last group of explanatory variables involved land management. Large water conservancy facilities exist to

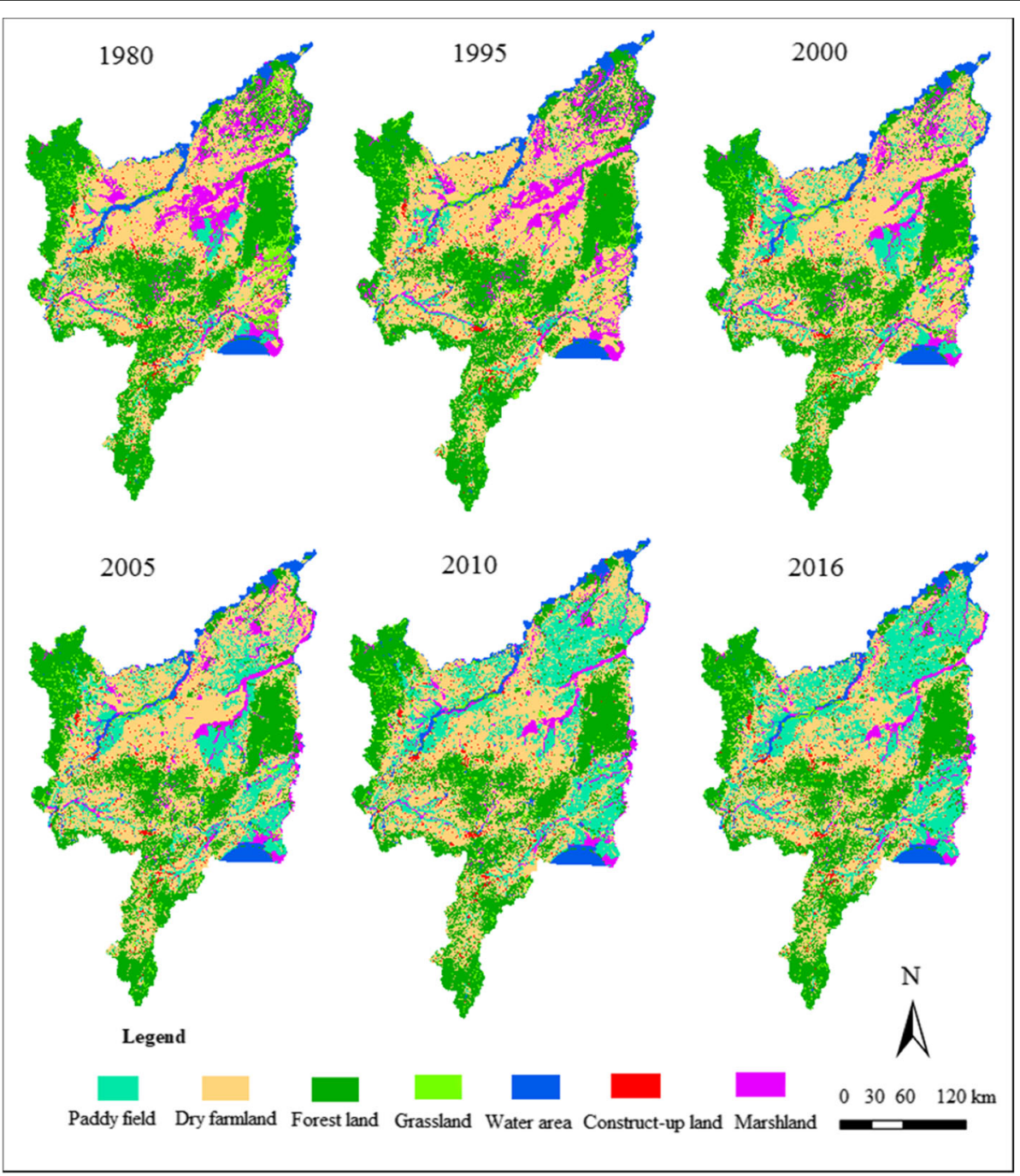

Fig. 2 Land cover maps of the study area from 1980 to 2016 


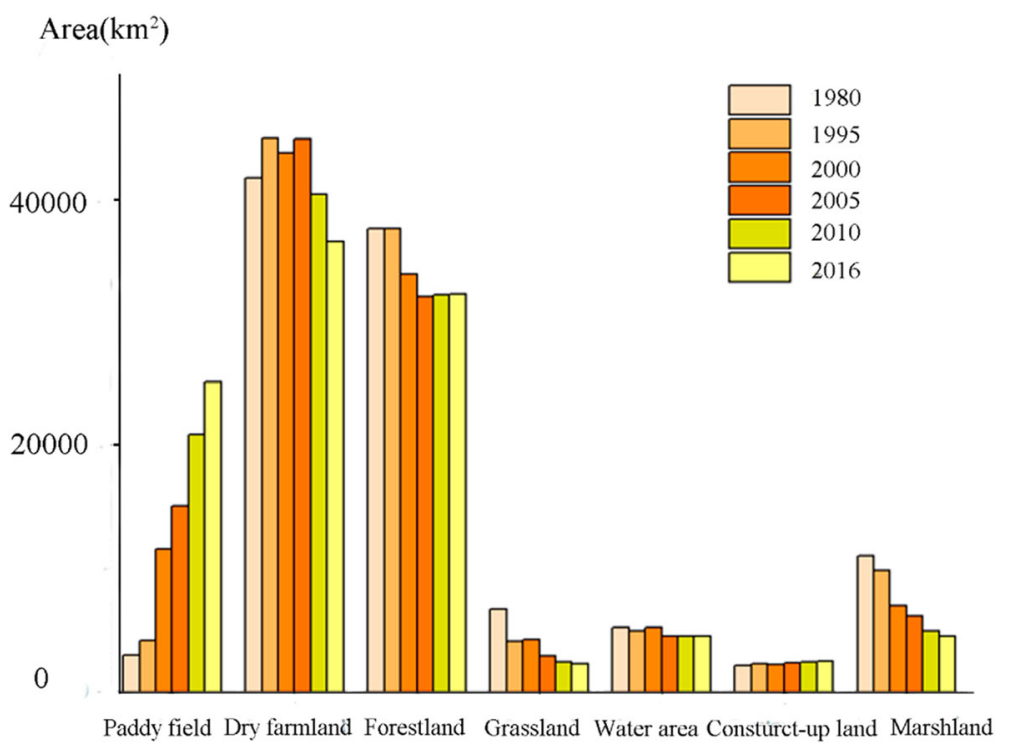

Fig. 3 Areas of different land use types in different years

prevent the natural disasters (e.g., flood, drought) or irrigate paddy field, which altered the regional hydrological process. Therefore, we included (1) ditch density.

\section{Results}

\section{Land use change of the Sanjiang Plain}

Classification accuracy was assessed with 216 field survey points in 2016, and historical land use information was collected from local elderly residents. The accuracies of interpretation were $89.6 \%, 88.6 \%, 84.2 \%, 86.4 \%, 88.6 \%$, and $91.2 \%$ for $1980,1995,2000,2005,2010$, and 2016, respectively.

The distributions and areas of the different land use types in 1980, 1995, 2000, 2005, 2010, and 2016 are shown in Fig. 2. The significant land use changes in the study area were declining marshland and increasing paddy field. In 1980, marshland accounted for approximately $11,862 \mathrm{~km}^{2}$, or $11.10 \%$ of the total area, while at the end of the period, the marshland area decreased by $65.7 \%$ to $4490 \mathrm{~km}^{2}$. However, the proportion of paddy field increased by $19.5 \%$. The area of dry farmland witnessed an obvious increase from 1980 to 2005, and after 2005, the area of dry farmland severely decreased. The areas of forestland and grassland decreased by $5597 \mathrm{~km}^{2}$ and $3785 \mathrm{~km}^{2}$ from 1980 to 2005, respectively. Then, the area of forestland increased by $195 \mathrm{~km}^{2}$, and the area of grassland further decreased by $590 \mathrm{~km}^{2}$. Moreover, the area of built-up land increased slowly, increasing by $309 \mathrm{~km}^{2}$. Surprisingly, the water area decreased by $752 \mathrm{~km}^{2}$ (Fig. 3), which was caused by the water-drainage construction.

The land use changed dramatically during 1980-2016 (Table 3). The single land use dynamic degrees of paddy field, grassland, and marshland were $20.99 \%$, - $1.82 \%$, and $-1.65 \%$, respectively. This result revealed that paddy field, grassland, and marshland changed significantly during 1980-2016. However, the single land use

Table 3 Single land use dynamic degree

\begin{tabular}{llllllll}
\hline Period & Paddy field (\%) & Dry farmland (\%) & Forestland (\%) & Grassland (\%) & Water area (\%) & Built-up (\%) & Marshland (\%) \\
\hline $1980-1995$ & 2.63 & 0.51 & -0.01 & -2.61 & -0.38 & 0.29 & -0.73 \\
$1995-2000$ & 36.50 & -0.53 & -1.97 & 0.70 & 1.15 & -1.00 & -0.53 \\
$2000-2005$ & 6.01 & 0.50 & -1.07 & -6.28 & -2.78 & 0.80 & -2.38 \\
$2005-2010$ & 7.69 & -2.01 & 0.09 & -3.14 & 0.14 & 1.53 & -3.93 \\
$2010-2016$ & 3.42 & -1.57 & 0.02 & -0.96 & -0.15 & 0.51 & -1.43 \\
$1980-2016$ & 20.99 & -0.34 & -0.40 & -1.82 & -0.40 & 0.40 & -1.65 \\
\hline
\end{tabular}


dynamic degrees of dry farmland, forestland, and builtup land were all lower than $0.5 \%$.

Figure 4 shows the marshland areas that were converted to other land use types at different time intervals. The area of marshland that were converted to dry farmland and paddy field was $3911 \mathrm{~km}^{2}$, and $3888 \mathrm{~km}^{2}$, which accounted for $32.97 \%$ and $32.78 \%$ of the total marshland area from 1980-2016, respectively. This finding indicated that marshland loss was mainly caused by agricultural reclamation. Temporal and spatial variation of marshland loss was apparent. During the early stage (e.g., 1980-1995, 1995-2000), marshland was mostly converted to dry farmland. During the latter stage (e.g., 2000-2005, 2010-2016), marshland was mostly reclamation into paddy field. Marshland loss occurred from upstream to downstream of the river during 1980-2016.
Meanwhile, from 1980 to 2005, marshland loss mostly occurred around large wetlands. During 2005-2016, marshland loss was scattered.

\section{Landscape pattern change analysis}

The landscape-level pattern of the study area was described by the NP, LSI, CONTAG, COHESION, SHDI, and SHEI (Fig. 5). From 1980 to 2016, the NP showed a slight decrease at the initial stage and then gradually significantly increased (Fig. 6). At the last stage, NP increased by 4363. From 1995 to 2016, the LSI exhibited sustained growth. The CONTAG increased by 3.45 and then gradually decreased. Compared to 1980 , the CONTAG in 2016 still increased by 0.28 . The COHESION remained steady. The SHDI and SHEI presented the same trend, which decreased at the initial stage and then

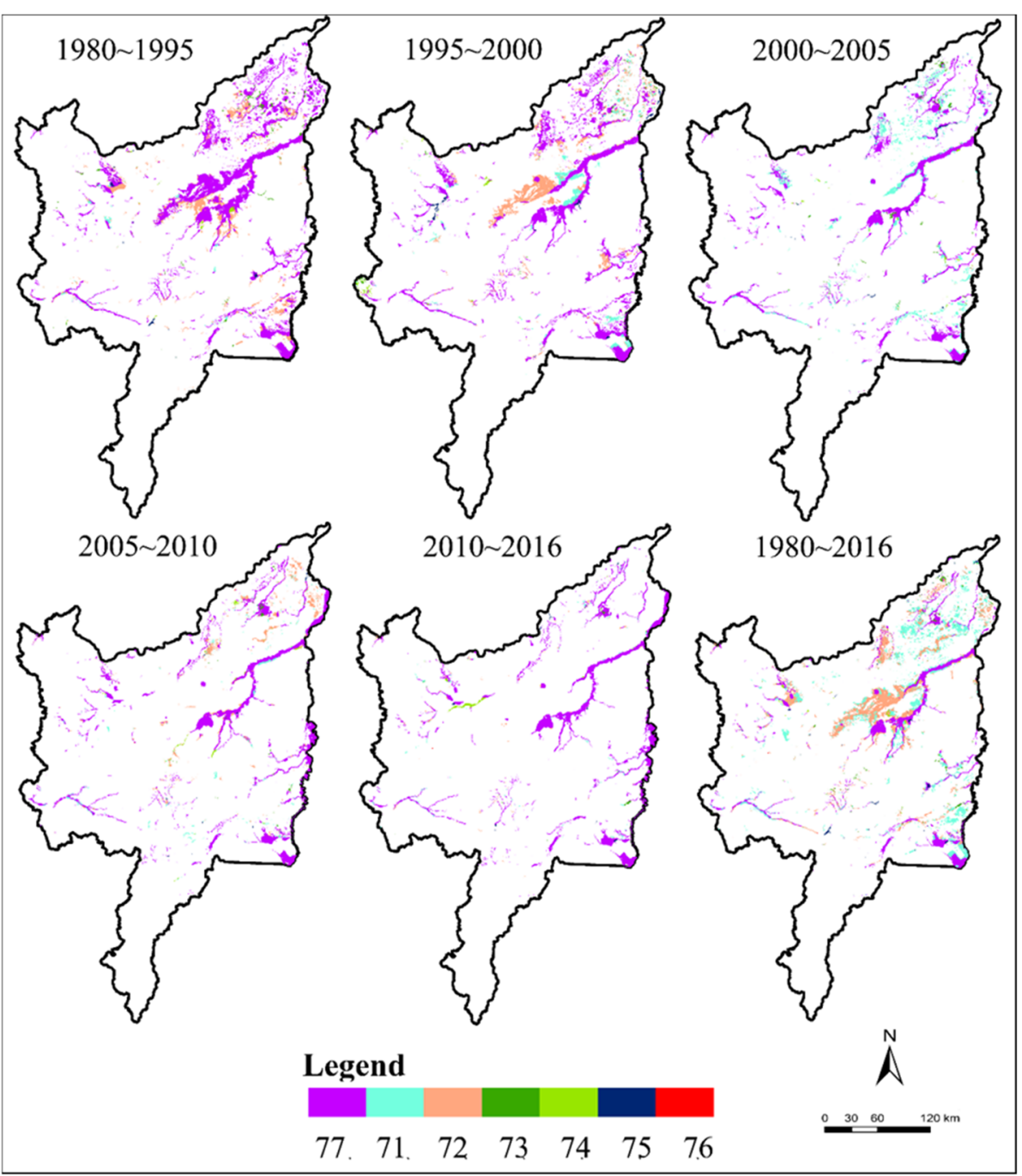

Fig. 4 Marshland transitions in the study area during 1980-2016. Notes: 71, marshland converted to paddy field; 72, marshland converted to dry farmland; 73, marshland converted to forestland; 74, marshland converted to grassland; 75, marshland converted to water area; 76, marshland converted to built-up land; and 77, steady marshland 


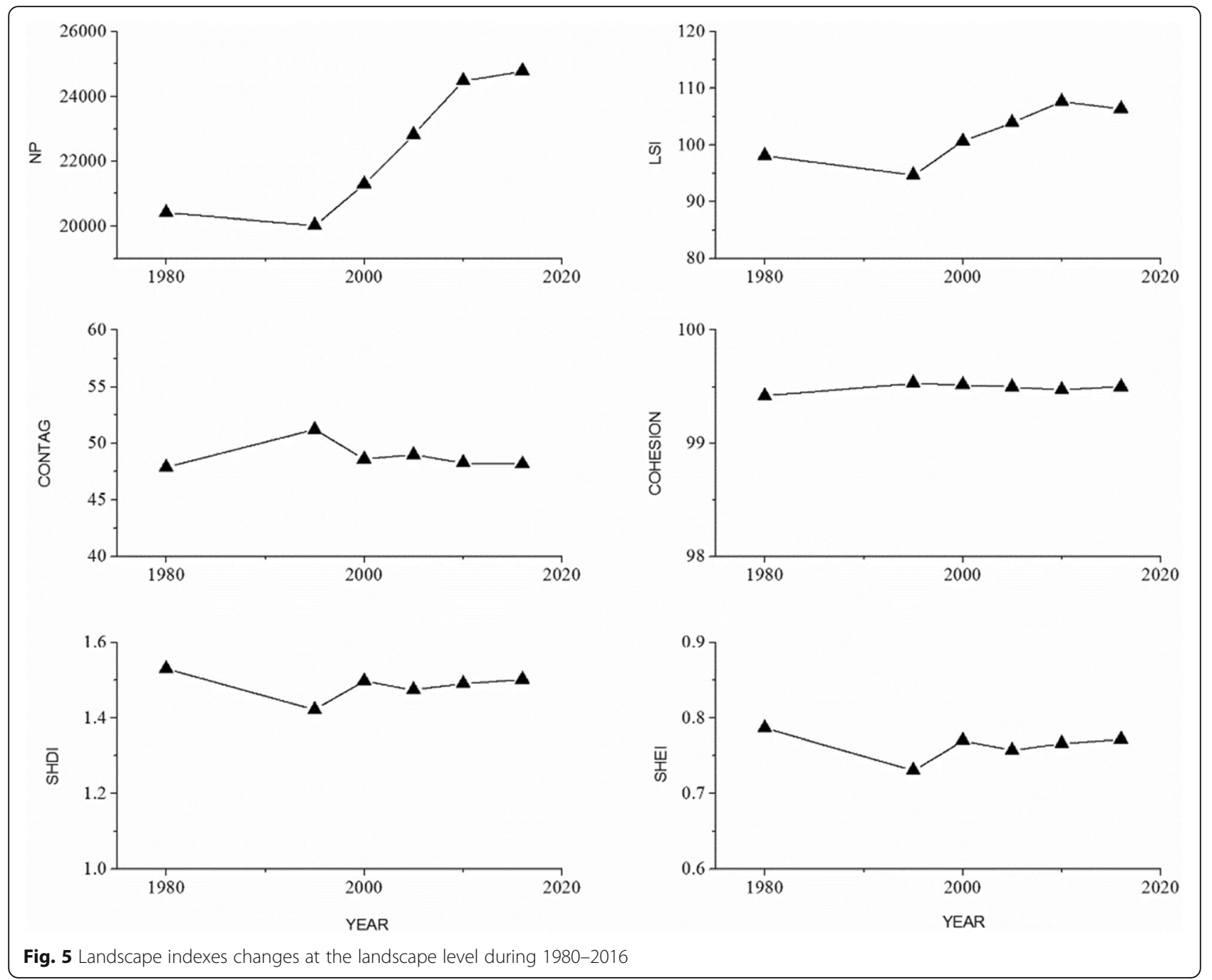

increased slowly. In summary, the landscape connectivity was not compact, and fragmentation was aggravated. It was because the dominant landscape (dry farmland) gradually decreased. Moreover, the turning points for all six landscape indices occurred in 1995. From 1980 to 1995, the NP, LSI, SHDI, and SHEI showed decreasing trends of landscape fragment. From 1995 to 2016, the trends of NP, LSI, SHDI, and SHDI gradually rebounded, which was driven by paddy field expand extremely.

The spatial configuration characteristics of marshland were indicated by the NP, LPI, ED, LSI, SPLIT, and COHESION (Fig. 6). The NP and LPI of marshland changed significantly, decreasing by 740 and 2.49 during 1980-2016, respectively. Distinctively, the largest change in NP occurred from 20052010, and the largest change in LPI occurred from 19952000. This result revealed that large patches tended to shrink or disappear from 1995-2000, and small patches tended to disappear from 2005-2010. The ED gradually decreased during 1980-2016, the possible because (1) the intensity of human activities became weaker and (2) natural wetland reserve boundaries were established to prevent the destruction of large wetland. The LSI decreased by $22.35 \%$. The SPLIT changed remarkably, and the COHESION changed slightly. During 2010-2016, all landscape metrics exhibited slower changes than earlier periods. The marshland has undergone remarkable shrinkage and fragmentation.

\section{Driving forces of marshland change}

The most important driving forces with "relative influence" were identified as the distance to river, potential crop yield, average annual temperature, average annual precipitation, population density, and ditch density, accounting for $20.6 \%, 20.2 \%, 9.5 \%, 9.4 \%, 8.6 \%$, and $8.4 \%$ of the total variance explained (Fig. 7). The relatively important factors were responsible for the marshland loss were the biophysical factors, socio-economic factors, and land management, which accounted for $65.2 \%, 25.5 \%$, and $8.4 \%$, respectively. 


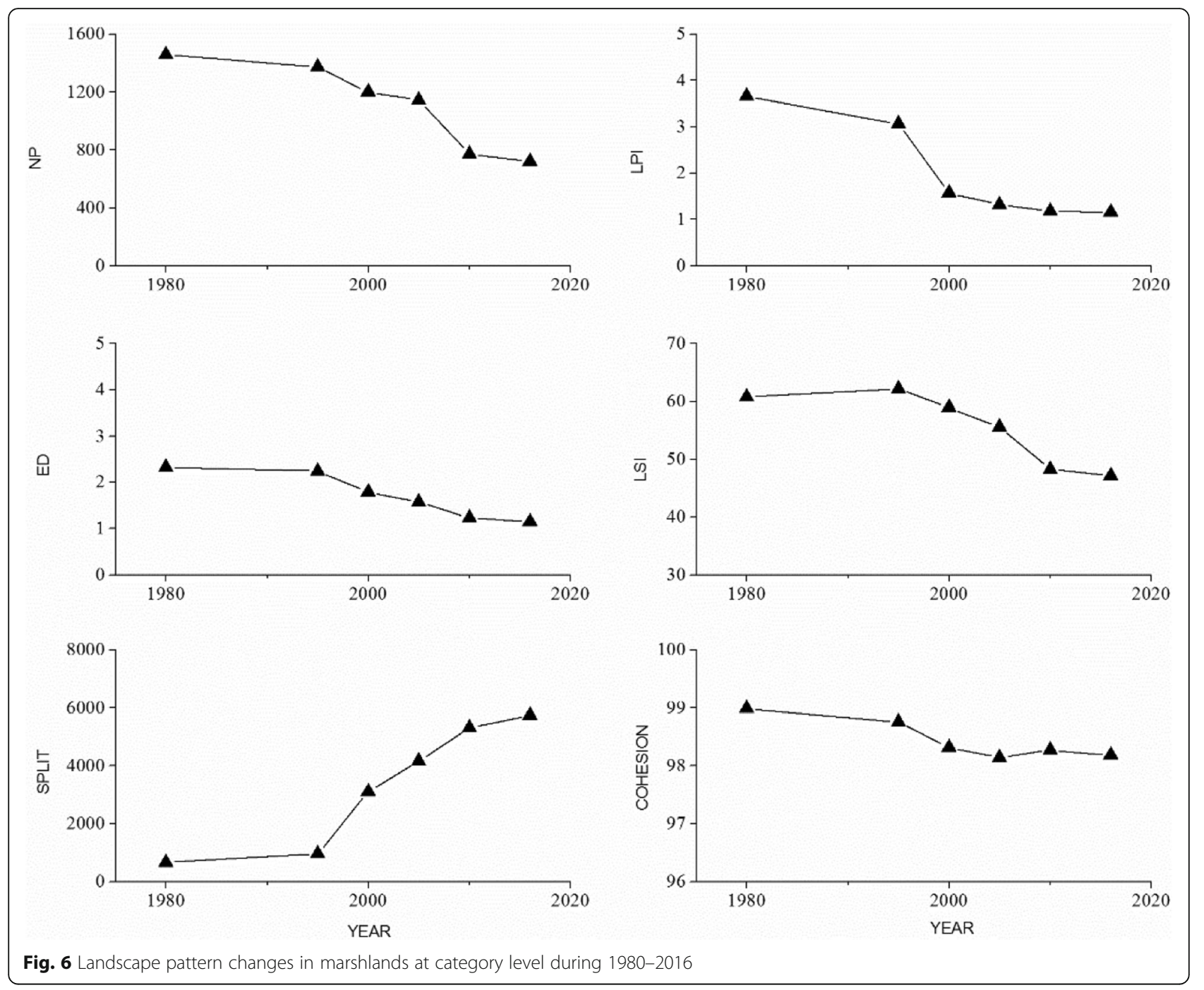

The partial dependency plots can be used to easily understand the relationship between marshland loss and driving forces (Fig. 8).

The most important variable explaining marshland loss in the Sanjiang Plain was distance to river, which indicated that the distribution of marshland was closely related to the distance to river. After an initial drastic increase in predicted marshland loss, marshland loss slowly declined beyond $5 \mathrm{~km}$ threshold value for the distance to river and became saturated when the distance to river beyond 25 $\mathrm{km}$. This indicated that when distance to river was less than $5 \mathrm{~km}$, reclamation by humans tended to increase with an increase in the distance to river leading to the marshland became vulnerable to loss. All the regions with distance to river greater than $5 \mathrm{~km}$ were predicted to be areas with intensive marshland loss.

The second most important variable was potential crop yield. The results showed that where the potential crop yield continued to increase, marshland loss was predicted to occur at high intensity. A possible explanation was that the marshland loss in the Sanjiang Plain was mainly due to agricultural reclamation, as marshland has high potential for production, and humans tended to reclamation these areas.

The annual average temperature and annual average precipitation were the most important variables following the potential crop yield. These variables maintained high level with several fluctuations. With an increase in the mean temperature, rice planting became favorable and stimulated reclamation, which indirectly caused marshland loss (Yan et al. 2017; Yan et al. 2018). An increase in paddy field aggravated the water shortages between marshland and cultivated land (Zou et al. 2018a, 2018b). Annual average precipitation was sensitive to runoff, so the marshland area severely fluctuated.

The ditch density and GDP were also important in explaining marshland loss. The ditch system promoted agricultural development but also altered regional 


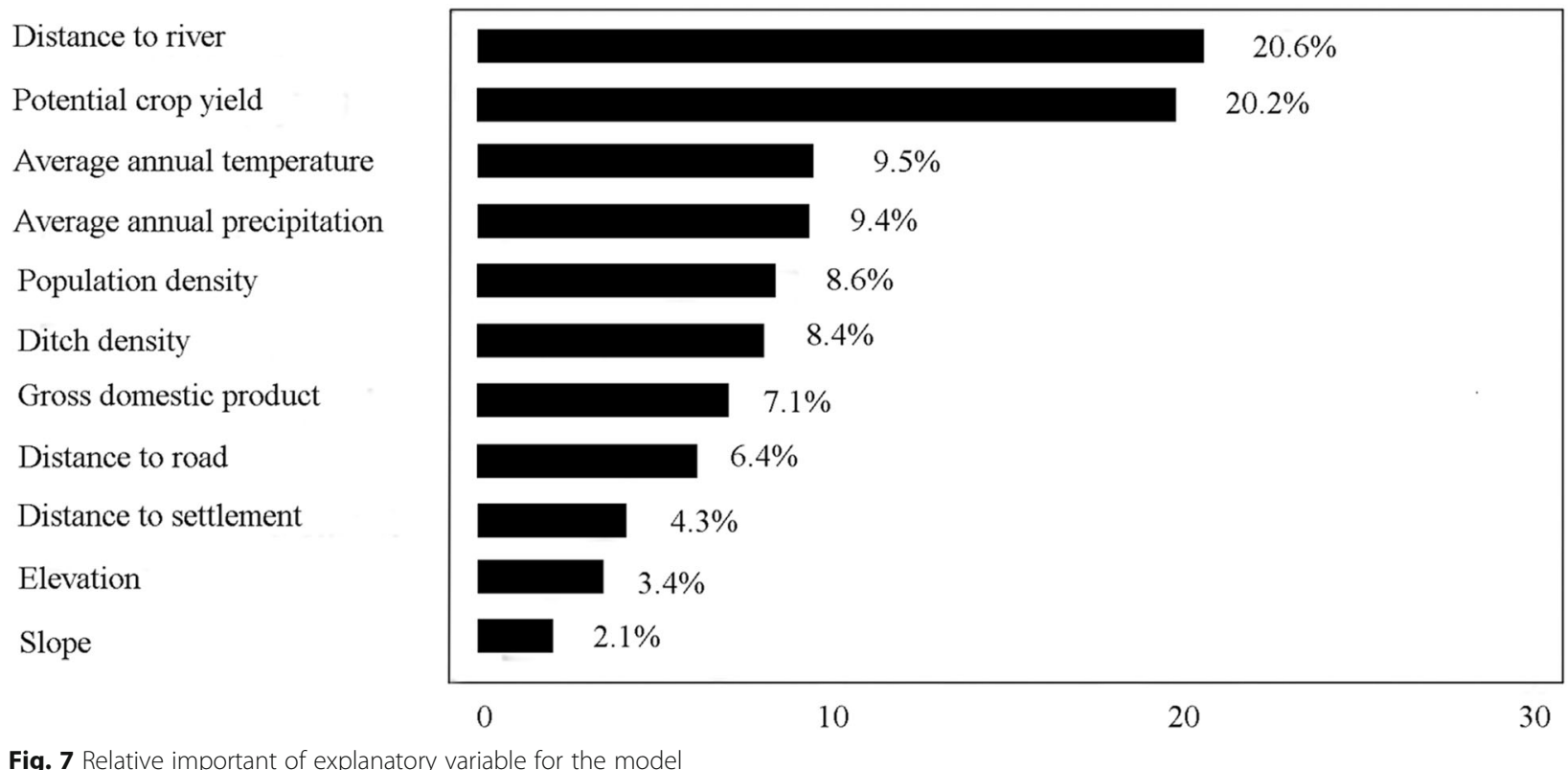

hydrology processes. With an increased in the GDP, the demand for living area or land would increase, which leaded to marshland loss.

In summary, human reclamation was responsible for large-scale marshland loss. Human decisions were the main driving force of marshland loss. The biophysical factors also affected the decisions by people and promoted marshland loss. Moreover, the climate factors (e.g., average annual precipitation and average annual temperature) also played a role in marshland loss.

\section{Discussion}

Comparison with land use change studies in the Sanjiang Plain

Land use interpretation accuracy was vital to analysis of land use change. To validate and improve the accuracies of land use data, great efforts have been made, including: field survey data, statistical data, and Google Earth image; historical land use information was collected from local elderly residents, as well as others related studies (Yan et al. 2017; Yan et al. 2018). To guarantee relatively high accuracy, visual interpretation was applied to interpret the land use maps. To reduce individual classification errors when land use change was detected, outlined land use maps by comparing images to images of different periods were applied. In general, interpretation accuracy was all above $84 \%$ and met the requirement for land use change detection. Paddy field expanded (increased by $22312 \mathrm{~km}^{2}$ ) and marshland loss (declined by $6558 \mathrm{~km}^{2}$ ) were predominated the long-term land use change from 1980 to 2016 in the study area. Rate of marshland loss was $30.37 \%$ higher, and other land use type change was consistent with previous studies (Yan et al. 2017; Yan et al. 2018). It was because the definition of marshland, e.g., wet meadow, was classified into neither grassland nor marshland in our study.

The marshland has undergone remarkable shrinkage and fragmentation (Wang et al. 2011; Liu et al. 2013; Yan et al. 2017; Liu et al. 2018). Compared with these studies, we found that the NP, LPI, ED, LSI, and COHESION of marshland decreased slowly at the initial period (19801995), and then decreased sharply (1995-2000, 20002005, 2005-2010), and became decreased gradually at the final period (2010-2016). And the SPLIT experienced opposite change: increased slowly during 1980-1995 and then increased considerably during 1995-2000, 20002005, 2005-2010 and became increased gradually during 2010-2016. Marshland landscape pattern changed during 2010-2016 was greatly different with that from 1986 to 2016. More attention should pay to the future marshland landscape pattern change, which was essential to scientific support for marshland protection.

\section{Driving forces of marshland loss}

Many studies indicate that marshland was related to population growth, technological progress, governmental policies, and climate change (Wang et al. 2011; Liu et al. 2013; Song et al. 2014; Yan et al. 2017). The population in the study area increased by $41 \%$ during 1982-2010 (Liu et al. 2013) and decreased by 6.96\% between 2011 and 2016. Marshland loss was closely related to governmental policy: "Agricultural Modernization" policy promoted use of modern machinery from 1978 to 1985 , which led to construction of modernized farms. Though 

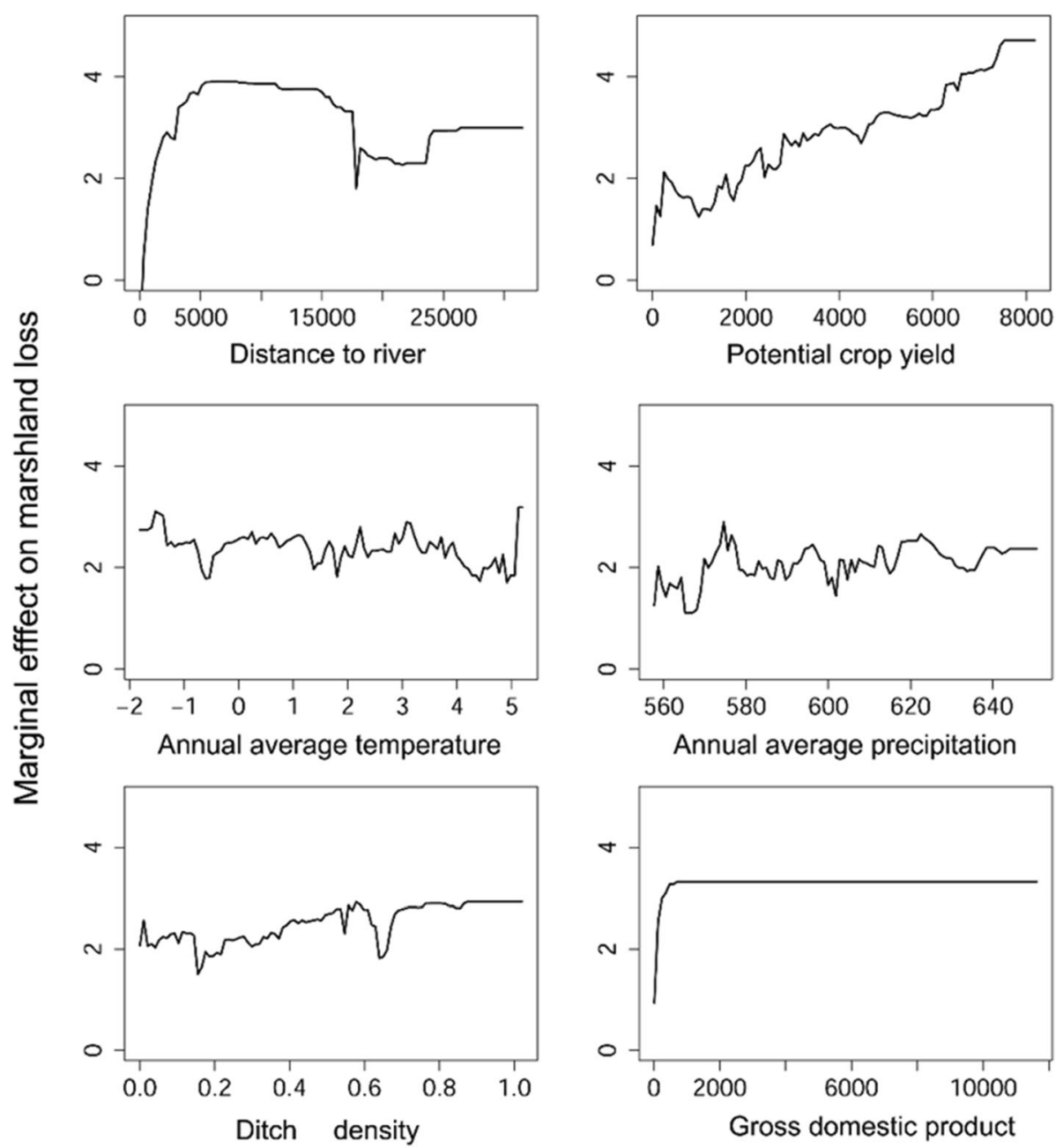

Fig. 8 The six most influential driving forces displayed on partial dependency plots

the national policy to stop development of the Sanjiang Plain in the 1990s, large area of marshland was still cultivated during 2000-2010. Marshland loss in a small scatter area was between 2010 and 2016.

Climate change may play an important role in the future. A marshland area-meteorological empirical model, habitat distribution model, and a trajectory analysis indicated that the contributions of climate change were 1730\% during 1954-2005, 4.33\% during 1981-2010, 30.9\% during 1980-2015 (Xue et al. 2015; Zhang et al. 2015; Chen et al. 2018). Contributions of annual average temperature and annual average precipitation were $9.5 \%$ and $9.4 \%$. Warm-dry change trends may be favorable for agricultural activities in cold regions, particularly paddy planting (Yan et al. 2017; Yan et al. 2018; Liu et al. 2018). Meanwhile, drought results in conversion of marshland into grassland (Sica et al. 2016). The area of conversion of marshland into grassland was $110 \mathrm{~km}^{2}$, which accounted for $25 \%$ of marshland loss during 2010-2016.
Advances in irrigation altered regional hydrological condition and provided convenient conditions for paddy planting. It was reported that with the length of ditches increased $1 \mathrm{~km}$, area of wetlands decreased by $0.23 \mathrm{~km}^{2}$ (Zou et al. 2018a, 2018b). It means that ditch regime not only changed the driving force of "distance to river" but also changed "ditch density", which played a key role in marshland loss. In return, paddy field expansion aggregated water use conflict between marshland and farmland (Zou et al. 2018a, 2018b). Additionally, irrigation regime may improve landscape connectivity, especially small patch marshland. Thus, it could alleviate marshland loss.

\section{Future study}

High spatial resolution remote sensing images are necessary to investigate marshland loss and pattern change in the Sanjiang Plain; more attention should pay on the small patch marshland, especially outsides the wetland nature reserves. By 2016, proportion of paddy field was 
approximate 25\%; paddy field expansion and aggregation occurred on the Sanjing plain need to pay continuous attention, which may lead to landscape reshaped. Water management infrastructure (e.g., ditch regimes, reservoirs, dam) is related to sustainable development of agriculture and marshland protection. It is vital to strengthen water management.

\section{Conclusions}

Marshland was rapidly changed by human reclamation, where $59.32 \%$ of marshland was lost over past 37 years in the Sanjiang Plain. Area of marshland loss gradually decreased, especially during $2010-2016\left(564 \mathrm{~km}^{2}\right)$. The lost areas were mainly converted to paddy field (40.07\%), dry farmland (24.82\%), and grassland (19.50\%). The landscape connectivity was not compact, and fragmentation was aggravated. With population dropping and crop yield rising, hydrological condition (e.g., distance to river, ditch density) and climate factors (e.g., average annual temperature, average annual precipitation) would play a more important role in marshland loss. Thus, effective water management was essential to implement for sustainable development of agriculture and marshland.

\begin{abstract}
Abbreviations
BRTs: Boosted regression trees; USGS: The United States Geological Survey Earth Resources Observation and Science Center; GDP: The gross domestic product; RESDC: The Data Center for Resources and Environment Sciences, Chinese Academy of Sciences; TM: Thematic Mapper; OLI: Operational Land Imager; NP: Number of patches; LSI: Landscape shape index; CONTAG: Contagion; COHESION: Patch cohesion index; SHDI: Shannon's diversity index; SHEl: Shannon's evenness index; LPI: Largest patch index; ED: Edge density; SPLIT: Splitting index; GIS: Geospatial information system
\end{abstract}

\section{Acknowledgements}

This research was supported by the National Key R\&D Program of China (No. 2016YFC0500401) and the Strategic Priority Research Program of the Chinese Academy of Sciences (XDA23070103).

\section{Authors' contributions}

Conceived and designed the experiments: Miao Liu, Zhen Li, and Zhenshan Xue. Analyzed the data: Zhen Li and Jinling Sui. Wrote the paper: Zhen Li. All authors read and approved the final manuscript.

\section{Funding}

This research was supported by the National Key R\&D Program of China (No. 2016YFC0500401) and the Strategic Priority Research Program of the Chinese Academy of Sciences (XDA23070103).

\section{Availability of data and materials}

The Landsat TM and OLI images are available at the United States Geological Survey Earth Resources Observation and Science Center (https://glovis.usgs. gov/), and the driving forces is available at the Data Center for Resources and Environmental Sciences, Chinese Academy of Sciences (RESDC) (http:// www.resdc.cn)

\section{Ethics approval and consent to participate}

Not applicable.

\section{Consent for publication}

Not applicable.

\section{Competing interests}

The authors declare that they have no competing interests.

\section{Author details}

${ }^{1}$ CAS Key Laboratory of Forest Ecology and Management, Institute of Applied Ecology, Chinese Academy of Sciences, Shenyang 110016, China. ${ }^{2}$ University of Chinese Academy of Sciences, Beijing 100049, China. ${ }^{3}$ Research Center of Wetland Ecology and Environment, Northeast Institute of Geography and Agroecology, Chinese Academy of Sciences, Changchun 130102, China. ${ }^{4}$ Key Laboratory of Urban Environment and Health, Institute of Urban

Environment, Chinese Academy of Sciences, Xiamen 361021, China.

Received: 22 December 2019 Accepted: 23 March 2020

Published online: 29 May 2020

\section{References}

Bullock A, Acreman M (2003) The role of wetlands in the hydrological cycle. Hydrol Earth Sys Sci 7(3):358-389. https://doi.org/10.5194/hess-7-358-2003

Chen H, Zhang WC, Gao HR, et al (2018) Climate change and anthropogenic impacts on wetland and agriculture in the Songnen and Sanjiang Plain, Northeast China. Remote Sens 10(3):25. https://doi.org/10.3390/rs10030356

Costanza R, Groot R, Sutton P, et al (2014) Changes in the global value of ecosystem services. Glob Env Change Hum Policy Dimen 26:152-158. https://doi.org/10.1016/j.gloenvcha.2014.04.002

Davidson NC (2014) How much wetland has the world lost? Long-term and recent trends in global wetland area. Mar Freshwater Res 65(10):934-941. https://doi.org/10.1071/mf14173

Davidson NC, Fluet-Chouinard E, Finlayson CM (2018) Global extent and distribution of wetlands: trends and issues. Mar Freshwater Res 69(4):620627. https://doi.org/10.1071/mf17019

Deegan LA, Johnson DS, Warren RS, et al (2012) Coastal eutrophication as a driver of salt marsh loss. Nature 490(7420):388-392. https://doi.org/10.1038/ nature11533

Dixon MJR, Loh J, Davidson NC, et al (2016) Tracking global change in ecosystem area: the Wetland Extent Trends index. Biol Conserv 193:27-35. https://doi. org/10.1016/j.biocon.2015.10.023

Dormann CF, Elith J, Bacher S, et al (2013) Collinearity: a review of methods to deal with it and a simulation study evaluating their performance. Ecography 36(1):27-46. https://doi.org/10.1111/j.1600-0587.2012.07348.x

Elith J, Graham CH, Anderson RP, et al (2006) Novel methods improve prediction of species' distributions from occurrence data. Ecography 29(2):129-151. https://doi.org/10.1111/j.2006.0906-7590.04596.x

Elith J, Leathwick JR, Hastie T (2008) A working guide to boosted regression trees. J Anim Ecol 77(4):802-813. https://doi.org/10.1111/j.1365-2656.2008. 01390.x

Feller IC, Friess DA, Krauss KW, et al (2017) The state of the world's mangroves in the 21st century under climate change. Hydrobiologia 803(1):1-12. https:// doi.org/10.1007/s10750-017-3331-z

Finlayson CM, Davidson NC, Spiers AG et al (1999) Global wetland inventory current status and future priorities. Mar Freshwater Res 50(8):717-727. https://doi.org/10.1071/mf99098

Geist HJ, Lambin EF (2002) Proximate causes and underlying driving forces of tropical deforestation. Bioscience 52(2):143-150. https://doi.org/10.1641/00063568(2002)052[0143:pcaudf]2.0.co;2

Junk WJ, An SQ, Finlayson CM et al (2013) Current state of knowledge regarding the world's wetlands and their future under global climate change: a synthesis. Aquat Sci 75(1):151-167. https://doi.org/10.1007/s00027-012-0278z

Lara MJ, Genet H, McGuire AD, et al (2016) Thermokarst rates intensify due to climate change and forest fragmentationin an Alaskan boreal forest lowland. Glob Change Biol 22(2):816-829. https://doi.org/10.1111/gcb.13124

Levers C, Butsic V, Verburg PH, et al (2016) Drivers of changes in agricultural intensity in Europe. Land Use Policy 58:380-393. https://doi.org/10.1016/j. landusepol.2016.08.013

Levers C, Verkerk PJ, Muller D, et al (2014) Drivers of forest harvesting intensity patterns in Europe. Forest Ecol Manag 315:160-172. https://doi.org/10.1016/ j.foreco.2013.12.030

Li XZ, He HS, Bu RC, et al (2005) The adequacy of different landscape metrics for various landscape patterns. Pattern Recog 38(12):2626-2638. https://doi.org/ 10.1016/j.patcog.2005.05.009

Li Y, Zhang Y, Zhang S (2002) The landscape pattern and ecologic effect of the marsh changes in the Sanjiang Plain. Scientia Geographica Sinica 22(6):677682. https://doi.org/10.3969/j.issn.1000-0690.2002.06.007 (in Chinese) 
Liu X, An Y, Dong G, et al (2018) Land use and landscape pattern changes in the Sanjiang Plain, Northeast China. Forests 9(10):637. https://doi.org/10.3390/ f9100637

Liu X, Dong G, Wang X, et al (2013) Characterizing the spatial pattern of marshlands in the Sanjiang Plain, Northeast China. Ecol Eng 53:335-342. https://doi.org/10.1016/j.ecoleng.2012.12.071

Mao DH, Luo L, Wang ZM, et al (2018a) Conversions between natural wetlands and farmland in China: a multiscale geospatial analysis. Sci Total Env 634: 550-560. https://doi.org/10.1016/j.scitotenv.2018.04.009

Mao DH, Wang ZM, Wu BF et al (2018b) Land degradation and restoration in the arid and semiarid zones of China: quantified evidence and implications from satellites. Land Degradation Dev 29(11):3841-3851. https://doi.org/10.1002/ldr.3135

Meng W, Hu B, He M, et al (2017) Temporal-spatial variations and driving factors analysis of coastal reclamation in China. Estuar Coast Shelf Sci 191:39-49. https://doi.org/10.1016/j.ecss.2017.04.008

Morris PJ, Swindles GT, Valdes PJ, et al (2018) Global peatland initiation driven by regionally asynchronous warming. Proc Natl Acad Sci U S A 115(19):48514856. https://doi.org/10.1073/pnas.1717838115

Müller D, Leitao PJ, Sikor T (2013) Comparing the determinants of cropland abandonment in Albania and Romania using boosted regression trees. Agric Sys 117:66-77. https://doi.org/10.1016/j.agsy.2012.12.010

Pekel JF, Cottam A, Gorelick N, et al (2016) High-resolution mapping of global surface water and its long-term changes. Nature 540(7633):418-422. https:// doi.org/10.1038/nature20584

Sica YV, Quintana RD, Radeloff VC, et al (2016) Wetland loss due to land use change in the Lower Parana River Delta, Argentina. Sci Total Environ 568: 967-978. https://doi.org/10.1016/j.scitotenv.2016.04.200

Song KS, Wang ZM, Du J, et al (2014) Wetland degradation: its driving forces and environmental impacts in the Sanjiang Plain, China. Environ Manag 54(2): 255-271. https://doi.org/10.1007/s00267-014-0278-y

Thomas N, Lucas R, Bunting P, et al (2017) Distribution and drivers of global mangrove forest change, 1996-2010. PLoS One 12(6):14. https://doi.org/10. 1371/journal.pone.0179302

Turetsky MR, Benscoter B, Page S, et al (2015) Global vulnerability of peatlands to fire and carbon loss. Nat Geosci 8(1):11-14. https://doi.org/10.1038/ngeo2325

USGS, 2016. United States geological survey earth resources observation and science data center. USGS global visualization viewer [WWW document]. (URL) http://glovis.usgs.gov/

van Asselen S, Verburg PH, Vermaat JE, et al (2013) Drivers of wetland conversion: a global meta-analysis. PLoS One 8(11):13. https://doi.org/10.1371/journal. pone.0081292

Wang ZM, Zhang B, Zhang SQ, et al (2006) Changes of land use and of ecosystem service values in Sanjiang Plain, Northeast China. Environ Monitor Assess 112(1-3):69-91. https://doi.org/10.1007/s10661-006-0312-5

Wendland KJ, Lewis DJ, Alix-Garcia J, et al (2011) Regional- and district-level drivers of timber harvesting in European Russia after the collapse of the Soviet Union. Glob Environ Change Hum Policy Dimen 21(4):1290-1300. https://doi.org/10.1016/j.gloenvcha.2011.07.003

Xiao DN, Yi Z, Sun ZW, et al (1990) Study on the variation of landscape pattern in the west suburbs of Shenyang. Chin J Appl Ecol 1(1):75-84 (in Chinese)

Xue ZS, Lyu XG, Zhang ZS, et al (2015) Influence of climate factors on marshes by habitat distribution models. Wetland Sci 13(3):315-321. https://doi.org/10. 13248/j.cnki.wetlandsci.2015.03.007 (in Chinese)

Yan FQ, Yu LX, Yang CB, et al (2018) Paddy field expansion and aggregation since the mid-1950s in a cold region and its possible causes. Remote Sens 10(3):18. https://doi.org/10.3390/rs10030384

Yan FQ, Zhang SW, Liu XT, et al (2017) Monitoring spatiotemporal changes of marshes in the Sanjiang Plain, China. Ecol Eng 104:184-194. https://doi.org/ 10.1016/j.ecoleng.2017.04.032

Zanella L, Folkard AM, Blackburn GA, et al (2017) How well does random forest analysis model deforestation and forest fragmentation in the Brazilian Atlantic forest? Environ Ecol Stat 24(4):529-549. https://doi.org/10.1007/s10651-017-0389-8

Zhang F, Kung HT, Vernaer CJ (2017) Assessment of land-cover/land-use change and landscape patterns in the two national nature reserves of Ebinur Lake Watershed, Xinjiang, China. Sustainability 9(5):724. https://doi.org/10.3390/su9050724

Zhang ZS, Xue ZS, Lyu XG, et al (2015) Quantitatively analysis of impact of climate change on areas of mires. Wetland Sci 13(2):161-165. https://doi. org/10.13248/j.cnki.wetlandsci.2015.02.004 (in Chinese)

Zou YC, Duan X, Xue ZS, et al (2018a) Water use conflict between wetland and agriculture. J Environ Manag 224:140-146. https://doi.org/10.1016/j.jenvman. 2018.07.052
Zou YC, Wang LY, Xue ZS, et al (2018b) Impacts of agricultural and reclamation practices on wetlands in the Amur River Basin, Northeastern China. Wetlands 38(2):383-389. https://doi.org/10.1007/s13157-017-0975-4

\section{Publisher's Note}

Springer Nature remains neutral with regard to jurisdictional claims in published maps and institutional affiliations.

\section{Submit your manuscript to a SpringerOpen ${ }^{\circ}$ journal and benefit from:}

- Convenient online submission

- Rigorous peer review

- Open access: articles freely available online

- High visibility within the field

- Retaining the copyright to your article

Submit your next manuscript at $\boldsymbol{\nabla}$ springeropen.com 